\title{
BILANGAN DOMINASI EDGE-VERTEX DAN VERTEX-EDGE PADA GRAF LINTASAN, CYCLE, CENTIPEDE DAN MASING-MASING MIDDLE GRAPHNYA
}

\author{
Evi Utami, Evi Noviani, Fransiskus Fran
}

\begin{abstract}
INTISARI
Sebuah himpunan $D \subseteq V, D$ adalah himpunan dominasi pada graf $G=(V, E)$ jika semua simpul yang tidak berada pada himpunan $D$ bertetangga sedikitnya dengan satu simpul dari $D$ dan kardinalitas minimum dari $D$ disebut bilangan dominasi $(\gamma(G))$. Ada banyak jenis bilangan dominasi yang telah dikembangkan diantaranya bilangan dominasi edge-vertex dan bilangan dominasi vertex-edge. Sebuah himpunan $S_{1} \subseteq E(G)$ adalah himpunan dominasi edge-vertex jika untuk semua simpul pada $G$ ada sisi e $\in$ $S_{1}$ sedemikian sehingga e mendominasi $v$ dan kardinalitas minimum dari $S_{1}$ disebut bilangan dominasi edge-vertex $\left(\gamma_{e v}(G)\right)$. Sebuah himpunan $S_{2} \subseteq V(G)$ adalah himpunan dominasi vertex-edge jika untuk semua sisi pada $G$ ada simpul $v \in S_{2}$ sedemikian sehingga $v$ mendominasi e dan kardinalitas minimum dari $S_{2}$ disebut bilangan dominasi vertex-edge $\left(\gamma_{v e}(G)\right)$. Hasil dari penelitian diperoleh bilangan dominasi edge-vertex pada graf lintasan, cycle dan centipede serta pada middle graph dari graf tersebut yaitu $\gamma_{e v}\left(P_{n}\right)=\left\lceil\frac{n}{4}\right\rceil, \gamma_{e v}\left(C_{n}\right)=\left\lceil\frac{n}{4}\right], \gamma_{e v}\left(P_{n}^{*}\right)=\left\lceil\frac{n}{2}\right], \gamma_{e v}\left(M\left(P_{n}\right)\right)=\left\lceil\frac{n}{3}\right], \gamma_{e v}\left(M\left(C_{n}\right)\right)=\left[\frac{n}{3}\right\rceil \operatorname{dan} \gamma_{e v}\left(M\left(P_{n}^{*}\right)\right)=n$. Bilangan dominasi vertex-edge pada graf lintasan, cycle dan centipede serta pada middle graph dari graf tersebut yaitu $\gamma_{v e}\left(P_{n}\right)=\left\lceil\frac{n-1}{4}\right\rceil, \gamma_{v e}\left(C_{n}\right)=\left\lceil\frac{n}{4}\right\rceil, \gamma_{v e}\left(P_{n}^{*}\right)=\left\lceil\frac{n}{3}\right\rceil, \gamma_{v e}\left(M\left(P_{n}\right)\right)=\left\lceil\frac{n-1}{3}\right\rceil, \gamma_{v e}\left(M\left(C_{n}\right)\right)=\left\lceil\frac{n}{3}\right\rceil$ dan $\gamma_{v e}\left(M\left(P_{n}^{*}\right)\right)=\left\lceil\frac{n}{2}\right]$.
\end{abstract}

Kata Kunci: bilangan dominasi, edge-vertex, vertex-edge, graf lintasan, cycle, centipede

\section{PENDAHULUAN}

Salah satu cabang ilmu matematika yang bermanfaat dan dapat menyelesaikan suatu kasus seperti membuat struktur organisasi dan rangkaian lisrik adalah teori graf. Teori graf pertama kali diperkenalkan oleh seorang matematikawan Swiss yang bernama Leonhard Euler pada tahun 1736 untuk menyelesaikan masalah jembatan Konigsberg [1]. Topik yang dibahas dalam teori graf salah satunya yaitu himpunan dominasi. Himpunan dominasi adalah suatu himpunan bagian $D$ dari himpunan simpul $V(G)$ dengan simpul-simpul yang tidak berada di $D$ bertetangga dengan minimal satu simpul di $D$. Kardinalitas minimum dari himpunan dominasi disebut dengan bilangan dominasi (domination number) dan dilambangkan dengan $\gamma(G)$ [2]. Pada kehidupan sehari-hari, himpunan dominasi dapat diterapkan sebagai contoh pemberhentian rute bus sekolah [3]. Dalam penelitian tersebut himpunan dominasi digambarkan sebagai titik-titik mana saja pemberhentian bus sekolah ditentukan. Sebagian besar rute bus sekolah beroperasi berdasarkan acuan tertentu. Biasanya aturan tersebut berupaya agar setiap anak berjalan tidak jauh ke tempat pemberhentian bus.

Terdapat beberapa topik mengenai bilangan dominasi diantaranya yaitu bilangan dominasi edgevertex dan bilangan dominasi vertex-edge. Bilangan dominasi edge-vertex pada graf $G$ adalah kardinalitas minimum dari himpunan dominasi edge-vertex pada $G$ dan dinotasikan sebagai $\gamma_{e v}(G)$ [4]. Bilangan dominasi vertex-edge adalah kardinalitas minimum dari himpunan dominasi vertex-edge pada $G$ dan dinotasikan sebagai $\gamma_{v e}(G)$ [5]. Pada penelitian [4] dan [5] telah dibahas bilangan dominasi edgevertex dan vertex-edge pada graf lintasan, cycle dan centipede. Pada penelitian ini mengembangkan penelitian sebelumnya dengan membuat graf baru dari graf lintasan, cycle dan centipede menggunakan konsep middle graph. Middle graph pada graf $G$ yang dinotasikan $M(G)$ adalah graf yang himpunan simpulnya adalah $V(G) \cup E(G)$ dan dua simpul bertetangga jika dan hanya jika keduanya adalah sisi 
yang bertetangga pada $G$ atau satu simpul pada $G$ dan yang lainnya bersisian dengan sisinya [6]. Jadi penelitian ini mencari formula bilangan dominasi edge-vertex dan vertex-edge pada graf lintasan, cycle dan centipede serta pada middle graph dari graf-graf tersebut.

\section{MIDDLE GRAPH}

Graf $G$ didefinisikan sebagai pasangan himpunan $(V, E)$, ditulis dengan notasi $G=(V, E)$, yang dalam hal ini $V$ adalah himpunan tidak-kosong dari simpul-simpul (vertices) dan $E$ adalah himpunan sisi (edges) yang menghubungkan sepasang simpul [1]. Dalam penelitian ini simpul pada graf dinyatakan dengan $u_{i}$ atau $v_{i}$ untuk $i \in \mathbb{N}$. Sedangkan sisi yang menghubungkan simpul $u$ dengan simpul $v$ dinyatakan dengan pasangan $(u, v)$.

Beberapa istilah yang berkaitan dengan graf yang digunakan dalam penelitian ini yaitu bertetangga (adjacent), bersisian (incident) dan derajat [1]. Dua buah simpul pada graf tak berarah $G$ dikatakan bertetangga bila keduanya terhubung langsung dengan sebuah sisi. Dengan kata lain, $u$ bertetangga dengan $v$ jika $(u, v)$ adalah sebuah sisi pada graf $G$. Untuk sembarang sisi $e=(u, v)$, sisi $e$ dikatakan bersisian dengan simpul $u$ dan $v$. Derajat suatu simpul pada graf tak berarah adalah jumlah sisi yang bersisian dengan simpul tersebut. Dinotasikan sebagai $d(v)$ yang menyatakan derajat simpul $v$.

Suatu graf dapat dibuat graf baru dengan menggunakan konsep middle graph. Berikut definisi terkait middle graph.

Definisi 1 [7] Middle graph pada graf $G$ yang dinotasikan $M(G)$ adalah graf yang himpunan simpulnya adalah $V(M(G))=V(G) \cup E(G)$. Dua simpul bertetangga jika dan hanya jika :

(i) $e_{a} \in V(M(G))$ bertetangga dengan $e_{b} \in V(M(G))$ karena sisi $e_{a}=v_{i} v_{j} \in E(G)$ dan sisi $e_{b}=$ $v_{j} v_{1} \in E(G)$ bersisian pada simpul yang sama di graf $G$.

(ii) $v_{i} \in V(M(G))$ bertetangga dengan $e_{a} \in V(M(G))$ karena sisi $e_{a}=v_{i} v_{j} \in E(G)$ bersisian dengan simpul $v_{i} \in V(G)$.

Bentuk middle graph dapat dilihat pada Gambar 1.

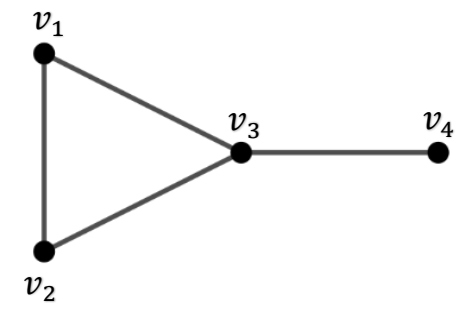

(a)

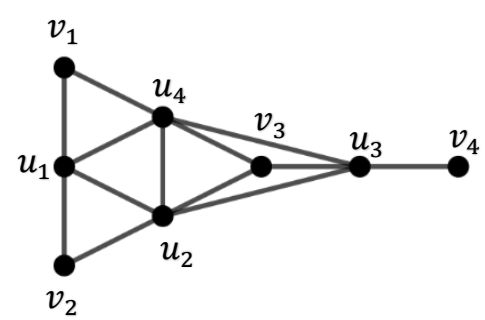

(b)

Gambar 1 (a) Graf $G$ dan (b) Graf $M(G)$

Pada Gambar 1, dapat dilihat perbedaan dari graf $G$ dan middle graph dari $G$. Gambar 1 (a) merupakan graf awal atau graf $G$ dan Gambar 1 (b) merupakan graf baru yang membentuk middle graph dari graf $G$.

\section{BILANGAN DOMINASI}

Secara historis, masalah dominasi mulai dipelajari dari tahun 1950 oleh Hedetniemi dan Laskar [2]. Definisi 2 [2] Diketahui graf $G=(V, E)$. Misalkan D merupakan subset dari V. Jika setiap simpul dari $V-D$ saling bertetangga sedikitnya dengan satu simpul dari $D$, maka $D$ dikatakan himpunan dominasi pada graf $G$. Bilangan dominasi dinotasikan dengan $\gamma(G)$ adalah kardinalitas minimum dari sebuah himpunan dominasi. 
Contoh 3 Misalkan diberikan graf $G$ seperti pada Gambar 2 dengan simpul warna hijau adalah simpul pada himpunan dominasi. Selanjutnya akan ditentukan bilangan dominasi pada graf $G$ tersebut.

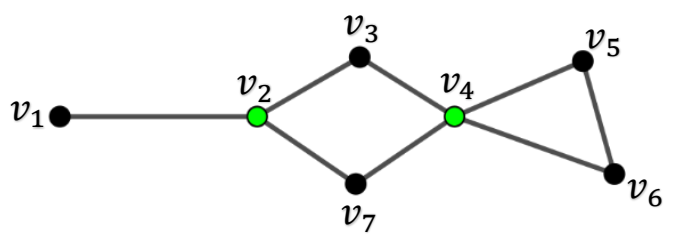

Gambar 2 Bilangan Dominasi pada Graf $G$

Pada Gambar 2 dapat dipilih beberapa kemungkinan himpunan dominasi pada graf $G$ yaitu $\left\{v_{1}, v_{3}, v_{4}\right\}$, $\left\{v_{1}, v_{3}, v_{5}, v_{7}\right\},\left\{v_{1}, v_{4}\right\}$ dan $\left\{v_{2}, v_{4}\right\}$. Berdasarkan beberapa kemungkinan, dapat ditentukan bilangan dominasi pada graf $G$ dengan kardinalitas minimum 2. Jadi bilangan dominasi pada graf $G$ yaitu 2 .

\section{BILANGAN DOMINASI EDGE-VERTEX DAN VERTEX-EDGE}

Salah satu pengembangan dari bilangan dominasi yaitu bilangan dominasi edge-vertex.

Definisi 4 [4] Diberikan graf $G=(V, E)$, sebuah sisi $e=(u, v) \in E(G)$ mendominasi sebuah simpul $w \in V(G) j i k a:$

(i) $u=w$ atau $v=w$ ( $w$ bersisian dengan e) atau

(ii) $(u, w)$ atau $(v, w)$ adalah sebuah sisi di $G$ ( $w$ bertetangga dengan $u$ atau $v)$.

Definisi 5 [4] Suatu himpunan $S \subseteq E(G)$ adalah himpunan dominasi edge-vertex dari G (atau himpunan dominasi-ev), jika untuk semua simpul $v \in V(G)$, terdapat sisi e $\in S$ sedemikian sehingga e mendominasi $v$. Bilangan dominasi-ev pada graf $G$ didefinisikan sebagai kardinalitas minimum dari himpunan dominasi-ev pada $G$ dan dinotasikan sebagai $\gamma_{e v}(G)$.

Pengembangan selanjutnya terkait bilangan dominasi yaitu bilangan dominasi vertex-edge.

Definisi 6 [5] Suatu himpunan simpul di G dikatakan sebuah himpunan dominasi vertex-edge, jika untuk semua sisi e $\in E(G)$ terdapat simpul $v \in S$ sedemikian sehingga $v$ mendominasi e. Simpul $u \in V(G)$ mendominasi sebuah sisi $(v, w) \in E(G)$ jika:

(i) $u=v$ atau $u=w(u$ bersisian degan $(v, w))$

(ii) $(u, v)$ atau $(u, w)$ adalah sisi di $G$ (u bersisian dengan sisi yang bertetangga dengan $v w)$.

Kardinalitas minimum dari himpunan dominasi vertex-edge disebut bilangan dominasi vertex-edge pada $G$ dan dinotasikan sebagai $\gamma_{v e}(G)[5]$.

\section{BILANGAN DOMINASI EDGE-VERTEX DAN VERTEX-EDGE PADA $P_{\boldsymbol{n}}$}

Graf lintasan dengan jumlah simpul berbeda memiliki pola bilangan dominasi edge-vertex dan vertex-edge pada graf lintasan, diperoleh lemma berikut :

Lemma 7 [8] Jika $P_{n}$ adalah graf lintasan $\operatorname{maka} \gamma_{v e}\left(P_{n}\right)=\left\lceil\frac{n-1}{4}\right\rceil, n>1$.

Untuk selanjutnya diperoleh formula bilangan dominasi edge-vertex pada graf lintasan.

Lemma 8 [4] Jika $P_{n}$ adalah graf lintasan maka $\gamma_{e v}\left(P_{n}\right)=\left\lceil\frac{n}{4}\right\rceil$.

Contoh 9 Diberikan graf lintasan dengan 3 simpul dan 2 sisi.

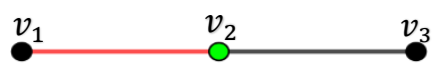

Gambar 3 Graf $P_{3}$

Dari Gambar 3 dapat dilihat himpunan dominasi vertex-edge pada graf $P_{3}$ yaitu $\left\{v_{2}\right\}$ dengan $v_{2}$ mendominasi sisi $\left\{\left(v_{1}, v_{2}\right),\left(v_{2}, v_{3}\right)\right\}$ sehingga diperoleh $\gamma_{v e}\left(P_{3}\right)=1$. Himpunan dominasi edge- 
vertex pada graf $P_{3}$ yaitu $\left\{\left(v_{1}, v_{2}\right)\right\}$ dengan $\left(v_{1}, v_{2}\right)$ mendominasi simpul $\left\{v_{1}, v_{2}, v_{3}\right\}$ sehingga diperoleh $\gamma_{e v}\left(P_{3}\right)=1$.

\section{BILANGAN DOMINASI EDGE-VERTEX DAN VERTEX-EDGE PADA $\boldsymbol{C}_{\boldsymbol{n}}$}

Graf cycle dengan jumlah simpul berbeda memiliki pola bilangan dominasi edge-vertex dan vertexedge pada graf cycle, diperoleh proposisi dan lemma berikut :

Proposisi 10 Jika $C_{n}$ adalah graf cycle maka $\gamma_{v e}\left(C_{n}\right)=\left\lceil\frac{n}{4}\right\rceil$.

Bukti : Diberikan graf cycle $\left(C_{n}\right)$ dengan $n$ simpul. Berdasarkan definisi graf cycle diketahui jumlah sisi sama dengan jumlah simpul sehingga himpunan simpul $V\left(C_{n}\right)=\left\{v_{1}, v_{2}, v_{3}, \ldots, v_{n}\right\}$, himpunan sisi $E\left(C_{n}\right)=\left\{\left(v_{1}, v_{2}\right),\left(v_{2}, v_{3}\right),\left(v_{3}, v_{4}\right), \ldots,\left(v_{n-1}, v_{n}\right),\left(v_{n}, v_{1}\right)\right\}$ dan derajat setiap simpulnya adalah 2 . Ambil $v_{i} \in V\left(C_{n}\right)$ dengan $i=3,4, \ldots, n-2$ sehingga $v_{i}$ mendominasi sisi $\left\{\left(v_{i-2}, v_{i-1}\right),\left(v_{i-1}, v_{i}\right)\right.$, $\left.\left(v_{i}, v_{i+1}\right),\left(v_{i+1}, v_{i+2}\right)\right\}$ karena berdasarkan definisi bilangan dominasi vertex-edge $v_{i}$ bersisian dengan $\left\{\left(v_{i-1}, v_{i}\right),\left(v_{i}, v_{i+1}\right)\right\}$ dan $v_{i}$ bersisian dengan sisi yang bertetangga dengan $\left\{\left(v_{i-1}, v_{i}\right),\left(v_{i}, v_{i+1}\right)\right\}$ yaitu $\left\{\left(v_{i-2}, v_{i-1}\right),\left(v_{i+1}, v_{i+2}\right)\right\}$. Akibatnya setiap simpul bisa mendominasi maksimal 4 sisi disekitarnya. Untuk $v_{i}$ lainnya, tidak bisa mendominasi lebih dari 4 sisi. Oleh karena itu dapat dipilih salah satu himpunan dominasi vertex-edge pada $C_{n}$ yaitu $\left\{v_{1}, v_{5}, v_{9}, \ldots, v_{4}\left[\frac{n}{4} \mid-3\right\}\right.$ sehingga diperoleh $\gamma_{v e}\left(C_{n}\right) \leq$ $\left\lceil\frac{n}{4}\right\rceil$. Selanjutnya akan ditunjukkan bilangan dominasi vertex-edge minimum pada graf cycle adalah $\gamma_{v e}\left(C_{n}\right)=\left\lceil\frac{n}{4}\right\rceil$. Andai $\gamma_{v e}\left(C_{n}\right)=\left\lceil\frac{n}{4}\right\rceil-1$, maka terdapat $\left\lceil\frac{n}{4}\right\rceil-1$ simpul yang merupakan kardinalitas minimum dari himpunan dominasi vertex-edge pada graf cycle. Jika terdapat $\left\lceil\frac{n}{4}\right\rceil-1$ simpul pada himpunan dominasi vertex-edge yang dipilih sembarang, maka mengakibatkan terdapat minimal satu sisi pada graf $C_{n}$ tidak terdominasi. Untuk $n=4 t-1$ maka terdapat 3 sisi tidak terdominasi, untuk $n=$ $4 t$ maka terdapat 4 sisi tidak terdominasi, untuk $n=4 t+1$ maka terdapat satu sisi tidak terdominasi dan untuk $n=4 t+2$ maka terdapat 2 sisi tidak terdominasi dengan $t \in \mathbb{N}$. Hal tersebut bertentangan dengan Definisi 6, dengan kata lain haruslah $\gamma_{v e}\left(C_{n}\right)=\left[\frac{n}{4}\right\rceil$. Jadi dapat disimpulkan bilangan dominasi vertex-edge pada graf cycle yaitu $\gamma_{v e}\left(C_{n}\right)=\left\lceil\frac{n}{4}\right\rceil$.

Untuk selanjutnya diperoleh formula bilangan dominasi edge-vertex pada graf cycle.

Lemma 11 [9] Jika $C_{n}$ adalah graf cycle maka $\gamma_{e v}\left(C_{n}\right)=\left\lceil\frac{n}{4}\right\rceil$

Contoh 12 Diberikan graf cycle dengan 3 simpul dan 3 sisi.

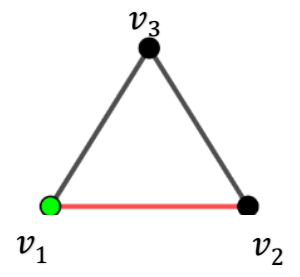

\section{Gambar 4 Graf $C_{3}$}

Dari Gambar 4 dapat dilihat himpunan dominasi vertex-edge pada graf $C_{3}$ yaitu $\left\{v_{1}\right\}$ dengan $v_{1}$ mendominasi sisi $\left\{\left(v_{1}, v_{2}\right),\left(v_{2}, v_{3}\right),\left(v_{1}, v_{3}\right)\right\}$ sehingga diperoleh $\gamma_{v e}\left(C_{3}\right)=1$. Himpunan dominasi edge-vertex pada graf $C_{3}$ yaitu $\left\{\left(v_{1}, v_{2}\right)\right\}$ dengan $\left(v_{1}, v_{2}\right)$ mendominasi simpul $\left\{v_{1}, v_{2}, v_{3}\right\}$ sehingga diperoleh $\gamma_{e v}\left(C_{3}\right)=1$.

\section{BILANGAN DOMINASI EDGE-VERTEX DAN VERTEX-EDGE PADA $P_{n}^{*}$}

Graf centipede dengan jumlah simpul berbeda memiliki pola bilangan dominasi edge-vertex dan vertex-edge pada graf centipede, diperoleh proposisi dan lemma berikut : 
Proposisi 13 Jika $P_{n}^{*}$ adalah graf centipede maka $\gamma_{v e}\left(P_{n}^{*}\right)=\left\lceil\frac{n}{3}\right\rceil$.

Bukti : Diberikan graf centipede $\left(P_{n}^{*}\right)$ dengan $n$-salinan graf $P_{2}$. Berdasarkan definisi graf centipede diketahui jumlah sisi sama dengan $2 n-1$ dan jumlah simpul sama dengan $2 n$ sehingga himpunan $\operatorname{simpul} V\left(P_{n}^{*}\right)=\left\{v_{1}, v_{2}, v_{3}, \ldots, v_{2 n}\right\}$, himpunan sisi $E\left(P_{n}^{*}\right)=\left\{\left(v_{1} v_{2}\right),\left(v_{2} v_{4}\right),\left(v_{3} v_{4}\right), \ldots,\left(v_{2 n-1} v_{2 n}\right)\right\}$ dan derajat simpul ganjil adalah 1 , derajat simpul genap adalah 3 kecuali simpul $\left\{v_{2}, v_{2 n}\right\}$ adalah 2 . Ambil $v_{i} \in V\left(P_{n}^{*}\right)$ dengan $i=6,8, \ldots, n-6, i$ genap dan $v_{i}$ simpul dengan derajat tertinggi sehingga $v_{i}$ mendominasi sisi $\left\{\left(v_{i-4}, v_{i-2}\right),\left(v_{i-3}, v_{i-2}\right),\left(v_{i-2}, v_{i}\right),\left(v_{i-1}, v_{i}\right),\left(v_{i}, v_{i+2}\right),\left(v_{i+1}, v_{i+2}\right)\right.$, $\left.\left(v_{i+2}, v_{i+4}\right)\right\}$ karena berdasarkan definisi bilangan dominasi vertex-edge $v_{i}$ bersisian dengan $\left\{\left(v_{i-2}, v_{i}\right),\left(v_{i-1}, v_{i}\right),\left(v_{i}, v_{i+2}\right)\right\}$ dan $v_{i}$ bersisian dengan sisi yang bertetangga dengan $\left\{\left(v_{i-2}, v_{i}\right)\right.$, $\left.\left(v_{i-1}, v_{i}\right),\left(v_{i}, v_{i+2}\right)\right\}$ yaitu $\left\{\left(v_{i-4}, v_{i-2}\right),\left(v_{i-3}, v_{i-2}\right),\left(v_{i+1}, v_{i+2}\right),\left(v_{i+2}, v_{i+4}\right)\right\}$. Akibatnya setiap simpul bisa mendominasi maksimal 7 sisi disekitarnya. Untuk $v_{i}$ lainnya, tidak bisa mendominasi lebih dari 7 sisi. Oleh karena itu dapat dipilih salah satu himpunan dominasi vertex-edge pada $P_{n}^{*}$ yaitu

(i) untuk $n=3 t+1, t \in \mathbb{N}$ maka himpunan dominasi vertex-edge yaitu $\left\{v_{2}, v_{8}, v_{14}, \ldots, v_{6}\left[\frac{n}{3}\right]_{-4}\right\}$,

(ii) untuk $n$ lainnya maka himpunan dominasi vertex-edge yaitu $\left\{v_{4}, v_{10}, v_{16}, \ldots, v_{6}\left[\frac{n}{3} \mid-2\right\}\right.$.

Sehingga diperoleh bilangan dominasi vertex-edge $\gamma_{v e}\left(P_{n}^{*}\right) \leq\left\lceil\frac{n}{3}\right\rceil$. Selanjutnya akan ditunjukkan bilangan dominasi vertex-edge minimum pada graf centipede adalah $\gamma_{v e}\left(P_{n}^{*}\right)=\left\lceil\frac{n}{3}\right\rceil$. Andai $\gamma_{v e}\left(P_{n}^{*}\right)=$ $\left\lceil\frac{n}{3}\right\rceil-1$, maka terdapat $\left\lceil\frac{n}{3}\right\rceil-1$ simpul yang merupakan kardinalitas minimum dari himpunan dominasi vertex-edge pada graf centipede. Jika terdapat $\left[\frac{n}{3}\right]-1$ simpul pada himpunan dominasi vertex-edge yang dipilih sembarang, bisa dipilih pada simpul yang mendominasi paling minimum yaitu 2 sisi sampai yang paling maksimum yaitu 7 sisi maka mengakibatkan terdapat minimal satu sisi pada graf $P_{n}^{*}$ tidak terdominasi. Untuk $n=3 t-1$ maka terdapat 2 sisi tidak terdominasi, untuk $n=3 t$ maka terdapat 4 sisi tidak terdominasi dan untuk $n=3 t+1$ maka terdapat satu sisi tidak terdominasi. Hal tersebut bertentangan dengan Definisi 6, dengan kata lain haruslah $\gamma_{v e}\left(P_{n}^{*}\right)=\left[\frac{n}{3}\right]$. Jadi dapat disimpulkan bilangan dominasi vertex-edge pada graf centipede yaitu $\gamma_{v e}\left(P_{n}^{*}\right)=\left\lceil\frac{n}{3}\right\rceil$.

Untuk selanjutnya diperoleh formula bilangan dominasi edge-vertex pada graf centipede.

Lemma 14 [4] Jika $P_{n}^{*}$ adalah graf centipede maka $\gamma_{e v}\left(P_{n}^{*}\right)=\left\lceil\frac{n}{2}\right\rceil$.

Contoh 15 Diberikan graf centipede dengan 2 salinan dan 3 sisi.

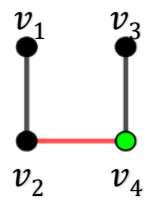

\section{Gambar 5 Graf $P_{2}^{*}$}

Dari Gambar 5 dapat dilihat himpunan dominasi vertex-edge pada graf $P_{2}^{*}$ yaitu $\left\{v_{4}\right\}$ dengan $v_{4}$ mendominasi sisi $\left\{\left(v_{1}, v_{2}\right),\left(v_{2}, v_{4}\right),\left(v_{3}, v_{4}\right)\right\}$ sehingga diperoleh $\gamma_{v e}\left(P_{2}^{*}\right)=1$. Himpunan dominasi edge-vertex pada graf $P_{2}^{*}$ yaitu $\left\{\left(v_{2}, v_{4}\right)\right\}$ dengan $\left(v_{2}, v_{4}\right)$ mendominasi simpul $\left\{v_{1}, v_{2}, v_{3}, v_{4}\right\}$ sehingga diperoleh $\gamma_{e v}\left(P_{2}^{*}\right)=1$. 


\section{BILANGAN DOMINASI EDGE-VERTEX DAN VERTEX-EDGE PADA M(P $\left.\boldsymbol{P}_{\boldsymbol{n}}\right)$}

Middle graph dari graf lintasan dengan jumlah simpul berbeda memiliki pola bilangan dominasi edge-vertex dan vertex-edge, diperoleh proposisi berikut :

Proposisi 16 Jika $M\left(P_{n}\right)$ adalah middle graph dari graf lintasan maka $\gamma_{v e}\left(M\left(P_{n}\right)\right)=\left\lceil\frac{n-1}{3}\right\rceil$.

Bukti : Diberikan graf lintasan $\left(P_{n}\right)$ dengan $n$ simpul. Berdasarkan definisi middle graph dapat diketahui jumlah sisi dari $M\left(P_{n}\right)$ sama dengan $3 n-4$ dan jumlah simpul sama dengan $2 n-1$ sehingga himpunan simpul $V\left(M\left(P_{n}\right)\right)=\left\{v_{1}, u_{1}, v_{2}, u_{2}, \ldots, u_{n-1}, v_{n}\right\}$ dan himpunan sisi $E\left(M\left(P_{n}\right)\right)=\left\{\left(v_{1}, u_{1}\right)\right.$, $\left.\left(v_{2}, u_{1}\right),\left(u_{1}, u_{2}\right),\left(v_{2}, u_{2}\right),\left(v_{3}, u_{2}\right), \ldots,\left(v_{n-1}, u_{n-1}\right),\left(v_{n}, u_{n-1}\right)\right\}$. Derajat simpul $\left\{v_{2}, v_{3}, v_{4}, \ldots, v_{n-1}\right\}$ adalah 2 kecuali $\left\{v_{1}, v_{n}\right\}$ derajat simpulnya adalah 1 dan derajat simpul $\left\{u_{2}, u_{3}, u_{4}, \ldots, u_{n-2}\right\}$ adalah 4 kecuali $\left\{u_{1}, u_{n-1}\right\}$ derajat simpulnya adalah 3. Ambil $u_{i} \in V\left(M\left(P_{n}\right)\right)$ dengan $i=3,4, \ldots, n-3$ dan $u_{i}$ merupakan simpul dengan derajat tertinggi sehingga $u_{i}$ mendominasi sisi $\left\{\left(u_{i-2}, u_{i-1}\right),\left(v_{i-1}, u_{i-1}\right)\right.$, $\left.\left(u_{i-1}, u_{i}\right),\left(v_{i}, u_{i-1}\right),\left(v_{i}, u_{i}\right),\left(u_{i}, u_{i+1}\right),\left(v_{i+1}, u_{i}\right),\left(v_{i+1}, u_{i+1}\right),\left(u_{i+1}, u_{i+2}\right),\left(v_{i+2}, u_{i+1}\right)\right\}$ karena berdasarkan definisi bilangan dominasi vertex-edge $u_{i}$ bersisian dengan $\left\{\left(u_{i-1}, u_{i}\right),\left(v_{i}, u_{i}\right),\left(u_{i}, u_{i+1}\right),\left(v_{i+1}, u_{i}\right)\right\}$ dan $u_{i}$ bersisian dengan sisi yang bertetangga dengan $\left\{\left(u_{i-1}, u_{i}\right),\left(v_{i}, u_{i}\right),\left(u_{i}, u_{i+1}\right),\left(v_{i+1}, u_{i}\right)\right\}$ yaitu $\left\{\left(u_{i-2}, u_{i-1}\right),\left(v_{i-1}, u_{i-1}\right),\left(v_{i}, u_{i-1}\right),\left(v_{i+1}, u_{i+1}\right)\right.$, $\left.\left(u_{i+1}, u_{i+2}\right),\left(v_{i+2}, u_{i+1}\right)\right\}$. Akibatnya setiap simpul bisa mendominasi maksimal 10 sisi disekitarnya. Untuk $u_{i}$ lainnya, tidak bisa mendominasi lebih dari 10 sisi. Oleh karena itu dapat dipilih salah satu himpunan dominasi vertex-edge pada $M\left(P_{n}\right)$ yaitu

(i) untuk $n=3 t-1, t \in \mathbb{N}$ maka himpunan dominasi vertex-edge yaitu $\left\{u_{1}, u_{4}, u_{7}, \ldots, u_{3}\left[\frac{n-1}{3}\right]-2\right\}$,

(ii) untuk $n$ lainnya maka himpunan dominasi vertex-edge yaitu $\left\{u_{2}, u_{5}, u_{8}, \ldots, u_{3}\left[\frac{n-1}{3}\right]-1\right\}$.

Sehingga diperoleh bilangan dominasi vertex-edge $\gamma_{v e}\left(M\left(P_{n}\right)\right) \leq\left\lceil\frac{n-1}{3}\right\rceil$. Selanjutnya akan ditunjukkan bilangan dominasi vertex-edge minimum pada middle graph dari graf lintasan adalah $\gamma_{v e}\left(M\left(P_{n}\right)\right)=$ $\left\lceil\frac{n-1}{3}\right\rceil$. Andai $\gamma_{v e}\left(M\left(P_{n}\right)\right)=\left\lceil\frac{n-1}{3}\right\rceil-1$, maka terdapat $\left\lceil\frac{n-1}{3}\right\rceil-1$ simpul yang merupakan kardinalitas minimum dari himpunan dominasi vertex-edge pada middle graph dari graf lintasan. Jika terdapat $\left\lceil\frac{n-1}{3}\right\rceil-1$ simpul pada himpunan dominasi vertex-edge yang dipilih sembarang, bisa dipilih pada simpul yang mendominasi paling minimum yaitu 3 sisi sampai yang paling maksimum yaitu 10 sisi maka mengakibatkan terdapat minimal satu sisi pada graf $M\left(P_{n}\right)$ tidak terdominasi. Untuk $n=3 t-1$ maka terdapat 2 sisi tidak terdominasi, untuk $n=3 t$ maka terdapat 4 sisi tidak terdominasi dan untuk $n=$ $3 t+1$ maka terdapat 7 sisi tidak terdominasi. Hal tersebut bertentangan dengan Definsii 6, dengan kata lain haruslah $\gamma_{v e}\left(M\left(P_{n}\right)\right)=\left\lceil\frac{n-1}{3}\right\rceil$. Jadi dapat disimpulkan bilangan dominasi vertex-edge pada middle graph dari graf lintasan yaitu $\gamma_{v e}\left(M\left(P_{n}\right)\right)=\left\lceil\frac{n-1}{3}\right\rceil$.

Untuk selanjutnya diperoleh formula bilangan dominasi edge-vertex pada graf $M\left(P_{n}\right)$.

Proposisi $17 \mathrm{Jika} M\left(P_{n}\right)$ adalah middle graph dari graf lintasan maka $\gamma_{e v}\left(M\left(P_{n}\right)\right)=\left\lceil\frac{n}{3}\right\rceil$.

Bukti : Ambil $\left(u_{i}, u_{i+1}\right) \in E\left(M\left(P_{n}\right)\right)$ dengan $i=2,3,4, \ldots, n-3$ dan $\left(u_{i}, u_{i+1}\right)$ sisi dengan derajat simpul penghubung tertinggi sehingga $\left(u_{i}, u_{i+1}\right)$ mendominasi simpul $\left\{u_{i-1}, v_{i}, u_{i}, v_{i+1}, u_{i+1}, v_{i+2}\right.$, $\left.u_{i+2}\right\}$ karena berdasarkan definisi bilangan dominasi edge-vertex $\left(u_{i}, u_{i+1}\right)$ bersisian dengan $\left\{u_{i}, u_{i+1}\right\}$ dan $\left(u_{i}, u_{i+1}\right)$ bertetangga dengan simpul $\left\{u_{i}, u_{i+1}\right\}$ yaitu $\left\{u_{i-1}, v_{i}, v_{i+1}, v_{i+2}, u_{i+2}\right\}$. Akibatnya setiap sisi bisa mendominasi maksimal 7 simpul disekitarnya. Untuk $\left(u_{i}, u_{i+1}\right)$ lainnya, tidak bisa mendominasi lebih dari 7 simpul. Oleh karena itu dapat dipilih salah satu himpunan dominasi edgevertex pada $M\left(P_{n}\right)$ yaitu 
(i) untuk $n=3 t-1, \quad t \in \mathbb{N}$ maka himpunan dominasi edge-vertex yaitu $\left\{\left(v_{1}, u_{1}\right)\right\} \cup$ $\left\{\left(u_{3\left(\left[\frac{n}{3}\right]-1\right)}, u_{3\left(\left[\frac{n}{3}\right]-1\right)+1}\right)\right\}$,

(ii) untuk $n=3 t, \quad t \in \mathbb{N}$ maka himpunan dominasi edge-vertex yaitu $\left\{\left(u_{1}, u_{2}\right),\left(u_{4}, u_{5}\right),\left(u_{7}, u_{8}\right), \ldots,\left(u_{3}\left[\frac{n}{3}\right]-2, u_{3}\left[\frac{n}{3}\right]-1\right)\right\}$,

(iii) untuk $n=3 t+1, \quad t \in \mathbb{N}$ maka himpunan dominasi edge-vertex yaitu $\left\{\left(v_{1}, u_{1}\right)\right\} \cup$ $\left\{\left(u_{3\left(\left[\frac{n}{3}\right]-1\right)-1}, u_{3\left(\left[\frac{n}{3}\right]-1\right)}\right)\right\}$.

Sehingga diperoleh bilangan dominasi edge-vertex $\gamma_{e v}\left(M\left(P_{n}\right)\right) \leq\left\lceil\frac{n}{3}\right\rceil$. Selanjutnya akan ditunjukkan bilangan dominasi vertex-edge minimum pada middle graph dari graf lintasan adalah $\gamma_{e v}\left(M\left(P_{n}\right)\right)=\left\lceil\frac{n}{3}\right\rceil$. Andai $\gamma_{e v}\left(M\left(P_{n}\right)\right)=\left\lceil\frac{n}{3}\right\rceil-1$, maka terdapat $\left\lceil\frac{n}{3}\right\rceil-1$ sisi yang merupakan kardinalitas minimum dari himpunan dominasi edge-vertex pada middle graph dari graf lintasan. Jika terdapat $\left\lceil\frac{n}{3}\right\rceil-1$ sisi pada himpunan dominasi edge-vertex yang dipilih sembarang, bisa dipilih pada sisi yang mendominasi paling minimum yaitu 4 simpul sampai yang paling maksimum yaitu 7 simpul maka mengakibatkan terdapat minimal satu simpul pada graf $M\left(P_{n}\right)$ tidak terdominasi. Untuk $n=3 t-1$ maka terdapat 2 simpul tidak terdominasi, untuk $n=3 t$ maka terdapat 4 simpul tidak terdominasi dan untuk $n=3 t+1$ maka terdapat satu simpul tidak terdominasi. Hal tersebut bertentangan dengan Definsii 5, dengan kata lain haruslah $\gamma_{e v}\left(M\left(P_{n}\right)\right)=\left[\frac{n}{3}\right]$. Jadi dapat disimpulkan bilangan dominasi edge-vertex pada middle graph dari graf lintasan yaitu $\gamma_{e v}\left(M\left(P_{n}\right)\right)=\left[\frac{n}{3}\right\rceil$.

\section{BILANGAN DOMINASI EDGE-VERTEX DAN VERTEX-EDGE PADA M( $\left.\boldsymbol{C}_{\boldsymbol{n}}\right)$}

Middle graph dari graf cycle dengan jumlah simpul berbeda memiliki pola bilangan dominasi edgevertex dan vertex-edge, diperoleh proposisi berikut :

Proposisi 18 Jika $M\left(C_{n}\right)$ adalah middle graph dari graf cycle maka $\gamma_{v e}\left(M\left(C_{n}\right)\right)=\left\lceil\frac{n}{3}\right\rceil$.

Bukti : Diberikan graf cycle $\left(C_{n}\right)$ dengan $n$ simpul. Berdasarkan definisi middle graph dapat diketahui jumlah sisi dari $M\left(C_{n}\right)$ sama dengan $3 n$ dan jumlah simpul sama dengan $2 n$ sehingga himpunan simpul $V\left(M\left(C_{n}\right)\right)=\left\{v_{1}, u_{1}, v_{2}, u_{2}, \ldots, v_{n}, u_{n}\right\}$ dan himpunan sisi $\left(M\left(C_{n}\right)\right)=\left\{\left(v_{1}, u_{1}\right),\left(u_{1}, u_{2}\right),\left(v_{2}, u_{2}\right)\right.$, $\left.\left(u_{2}, v_{3}\right), \ldots,\left(v_{n}, u_{n}\right),\left(u_{n}, v_{1}\right)\right\}$. Derajat simpul $\left\{v_{1}, v_{2}, v_{3}, \ldots, v_{n}\right\}$ adalah 2 dan derajat simpul $\left\{u_{1}, u_{2}, u_{3}, \ldots, u_{n}\right\}$ adalah 4. Ambil $u_{i} \in V\left(M\left(C_{n}\right)\right)$ dengan $i=3,4, \ldots, n-2$ dan $u_{i}$ simpul dengan derajat tertinggi sehingga $u_{i}$ mendominasi sisi $\left\{\left(u_{i-2}, u_{i-1}\right),\left(v_{i-1}, u_{i-1}\right),\left(u_{i-1}, v_{i}\right),\left(u_{i-1}, u_{i}\right),\left(v_{i}, u_{i}\right)\right.$, $\left.\left(u_{i}, v_{i+1}\right),\left(u_{i}, u_{i+1}\right),\left(v_{i+1}, u_{i+1}\right),\left(u_{i+1}, v_{i+2}\right),\left(u_{i+1}, u_{i+2}\right)\right\}$ karena berdasarkan definisi bilangan dominasi vertex-edge $u_{i}$ bersisian $\left\{\left(u_{i-1}, u_{i}\right),\left(v_{i}, u_{i}\right),\left(u_{i}, v_{i+1}\right),\left(u_{i}, u_{i+1}\right)\right\}$ dan $u_{i}$ bersisian dengan sisi yang bertetangga dengan $\left\{\left(u_{i-1}, u_{i}\right),\left(v_{i}, u_{i}\right),\left(u_{i}, v_{i+1}\right),\left(u_{i}, u_{i+1}\right)\right\}$ yaitu $\left\{\left(u_{i-2}, u_{i-1}\right),\left(v_{i-1}, u_{i-1}\right)\right.$, $\left.\left(u_{i-1}, v_{i}\right),\left(v_{i+1}, u_{i+1}\right),\left(u_{i+1}, v_{i+2}\right),\left(u_{i+1}, u_{i+2}\right)\right\}$. Akibatnya setiap simpul bisa mendominasi maksimal 10 sisi disekitarnya. Untuk $u_{i}$ lainnya, tidak bisa mendominasi lebih dari 10 sisi. Oleh karena itu dapat dipilih salah satu himpunan dominasi vertex-edge pada $M\left(C_{n}\right)$ yaitu $\left\{u_{1}, u_{4}, u_{7}, \ldots, u_{3}\left[\frac{n}{3}\right]-2\right\}$ sehingga diperoleh $\gamma_{v e}\left(M\left(C_{n}\right)\right) \leq\left[\frac{n}{3}\right]$. Selanjutnya akan ditunjukkan bilangan dominasi vertex-edge minimum pada middle graph dari graf cycle adalah $\gamma_{v e}\left(M\left(C_{n}\right)\right)=\left\lceil\frac{n}{3}\right\rceil$. Andai $\gamma_{v e}\left(M\left(C_{n}\right)\right)=\left\lceil\frac{n}{3}\right\rceil-1$, maka terdapat $\left\lceil\frac{n}{3}\right\rceil-1$ simpul yang merupakan kardinalitas minimum dari himpunan dominasi vertexedge pada middle graph dari graf cycle. Jika terdapat $\left[\frac{n}{3}\right]-1$ simpul pada himpunan dominasi vertexedge yang dipilih sembarang, bisa dipilih pada simpul yang mendominasi paling minimum yaitu 7 sisi sampai yang paling maksimum yaitu 10 sisi maka mengakibatkan terdapat minimal satu sisi pada graf 
$M\left(C_{n}\right)$ tidak terdominasi. Untuk $n=3 t$ maka terdapat 8 sisi yang tidak terdominasi, untuk $n=3 t+1$ maka terdapat 2 sisi yang tidak terdominasi dan untuk $n=3 t+2$ maka terdapat 5 sisi yang tidak terdominasi dengan $t \in \mathbb{N}$. Hal tersebut bertentangan dengan Definisi 6, dengan kata lain haruslah $\gamma_{v e}\left(M\left(C_{n}\right)\right)=\left\lceil\frac{n}{3}\right\rceil$. Jadi dapat disimpulkan bilangan dominasi vertex-edge pada middle graph dari graf cycle yaitu $\gamma_{v e}\left(M\left(C_{n}\right)\right)=\left\lceil\frac{n}{3}\right\rceil$.

Untuk selanjutnya diperoleh formula bilangan dominasi edge-vertex pada graf $M\left(C_{n}\right)$.

Proposisi $19 \mathrm{Jika} M\left(C_{n}\right)$ adalah middle graph dari graf cycle maka $\gamma_{e v}\left(M\left(C_{n}\right)\right)=\left\lceil\frac{n}{3}\right\rceil$.

Bukti : Ambil $\left(u_{i}, u_{i+1}\right) \in E\left(M\left(C_{n}\right)\right)$ dengan $i=2,3,4, \ldots, n-2$ dan $\left(u_{i}, u_{i+1}\right)$ sisi dengan derajat simpul penghubung tertinggi sehingga $\left(u_{i}, u_{i+1}\right)$ mendominasi simpul $u_{i-1}, v_{i}, u_{i}, v_{i+1}, u_{i+1}, v_{i+2}$, $\left.u_{i+2}\right\}$ karena berdasarkan definisi bilangan dominasi edge-vertex $\left(u_{i}, u_{i+1}\right)$ bersisian dengan $\left\{u_{i}, u_{i+1}\right\}$ dan $\left(u_{i}, u_{i+1}\right)$ bertetangga dengan simpul $\left\{u_{i}, u_{i+1}\right\}$ yaitu $\left\{u_{i-1}, v_{i}, v_{i+1}, v_{i+2}, u_{i+2}\right\}$. Akibatnya setiap sisi bisa mendominasi maksimal 7 simpul disekitarnya. Untuk $\left(u_{i}, u_{i+1}\right)$ lainnya, tidak bisa mendominasi lebih dari 7 simpul. Oleh karena itu dapat dipilih salah satu himpunan dominasi edgevertex pada $M\left(C_{n}\right)$ yaitu

(i) untuk $n=3 t+1, \quad t \in \mathbb{N}$ maka himpunan dominasi edge-vertex yaitu $\left\{\left(u_{1}, u_{2}\right),\left(u_{4}, u_{5}\right),\left(u_{7}, u_{8}\right), \ldots,\left(u_{3}\left[\frac{n}{3} \mid-2, u_{1}\right)\right\}\right.$,

(ii) untuk $n$ lainnya maka himpunan dominasi edge-vertex yaitu $\left\{\left(u_{1}, u_{2}\right),\left(u_{4}, u_{5}\right),\left(u_{7}, u_{8}\right), \ldots,\left(u_{3}\left|\frac{n}{3}\right|-2, u_{3}\left[\frac{n}{3}\right]-1\right)\right\}$.

Sehingga diperoleh bilangan dominasi edge-vertex $\gamma_{e v}\left(M\left(C_{n}\right)\right) \leq\left[\frac{n}{3}\right]$. Selanjutnya akan ditunjukkan bilangan dominasi vertex-edge minimum pada middle graph dari graf cycle adalah $\gamma_{e v}\left(M\left(C_{n}\right)\right)=\left\lceil\frac{n}{3}\right\rceil$. Andai $\gamma_{e v}\left(M\left(C_{n}\right)\right)=\left\lceil\frac{n}{3}\right\rceil-1$, maka terdapat $\left\lceil\frac{n}{3}\right\rceil-1$ sisi yang merupakan kardinalitas minimum dari himpunan dominasi edge-vertex pada middle graph dari graf cycle. Jika terdapat $\left\lceil\frac{n}{3}\right\rceil-1$ sisi pada himpunan dominasi edge-vertex yang dipilih sembarang, bisa dipilih pada sisi yang mendominasi paling minimum yaitu 5 simpul sampai yang paling maksimum yaitu 7 simpul maka mengakibatkan terdapat minimal satu simpul pada graf $M\left(C_{n}\right)$ tidak terdominasi. Untuk $n=3 t$ maka terdapat 5 simpul yang tidak terdominasi, untuk $n=3 t+1$ maka terdapat satu simpul yang tidak terdominasi dan untuk $n=$ $3 t+2$ maka terdapat 3 simpul yang tidak terdominasi. Hal tersebut bertentangan dengan Definisi 5 , dengan kata lain haruslah $\gamma_{e v}\left(M\left(C_{n}\right)\right)=\left\lceil\frac{n}{3}\right\rceil$. Jadi dapat disimpulkan bilangan dominasi edge-vertex pada middle graph dari graf cycle yaitu $\gamma_{e v}\left(M\left(C_{n}\right)\right)=\left\lceil\frac{n}{3}\right\rceil$.

\section{BILANGAN DOMINASI EDGE-VERTEX DAN VERTEX-EDGE PADA M(P)}

Middle graph dari graf centipede dengan jumlah simpul berbeda memiliki pola bilangan dominasi edge-vertex dan vertex-edge, diperoleh proposisi berikut :

Proposisi $20 \mathrm{Jika} M\left(P_{n}^{*}\right)$ adalah middle graph dari graf centipede maka $\gamma_{v e}\left(M\left(P_{n}^{*}\right)\right)=\left\lceil\frac{n}{2}\right\rceil$.

Bukti : Diberikan graf cetipede $\left(P_{n}^{*}\right)$ dengan $n$-salinan dari graf $P_{2}$. Berdasarkan definisi middle graph dapat diketahui jumlah sisi dari $M\left(P_{n}^{*}\right)$ sama dengan $7 n-6$ dan jumlah simpul sama dengan $4 n-1$ sehingga himpunan simpul $V\left(M\left(P_{n}^{*}\right)\right)=\left\{v_{1}, u_{1}, v_{2}, u_{2}, \ldots, v_{2 n-1}, u_{2 n-1}, v_{2 n}\right\}$ dan himpunan sisi $E\left(M\left(P_{n}^{*}\right)\right)=\left\{\left(v_{1}, u_{1}\right),\left(u_{1}, v_{2}\right),\left(u_{1}, u_{2}\right),\left(v_{2}, u_{2}\right),\left(u_{2}, v_{3}\right),\left(u_{2}, v_{4}\right),\left(u_{2}, u_{4}\right), \ldots,\left(v_{2 n-1}, u_{2 n-1}\right)\right.$, $\left.\left(u_{2 n-1}, v_{2 n}\right)\right\}$. Derajat simpul $\left\{v_{1}, v_{3}, v_{5}, \ldots, v_{2 n-1}\right\}$ adalah 1 , derajat simpul $\left\{v_{4}, v_{6}, \ldots, v_{2 n-2}\right\}$ adalah 3 , derajat simpul $\left\{v_{2}, v_{2 n}\right\}$ adalah 2 , derajat simpul $\left\{u_{3}, u_{5}, \ldots, u_{2 n-3}\right\}$ adalah 4 , derajat simpul $\left\{u_{1}, u_{2 n-1}\right\}$ adalah 3 , derajat simpul $\left\{u_{4}, u_{6}, \ldots, v_{2 n-4}\right\}$ adalah 6 dan derajat simpul $\left\{u_{2}, u_{2 n-2}\right\}$ adalah 
5. Ambil $u_{i} \in V\left(M\left(P_{n}^{*}\right)\right)$ dengan $i=6,8, \ldots, 2 n-6, i$ genap dan $u_{i}$ simpul dengan derajat tertinggi sehingga $u_{i}$ mendominasi sisi $\left\{\left(u_{i-4}, u_{i-2}\right),\left(u_{i-3}, u_{i-2}\right),\left(v_{i-2}, u_{i-2}\right),\left(u_{i-2}, u_{i-1}\right),\left(u_{i-2}, u_{i}\right)\right.$, $\left(v_{i}, u_{i-2}\right),\left(v_{i-1}, u_{i-1}\right),\left(u_{i-1}, u_{i}\right),\left(v_{i}, u_{i}\right),\left(v_{i}, u_{i-1}\right),\left(v_{i+2}, u_{i}\right),\left(u_{i}, u_{i+1}\right),\left(u_{i}, u_{i+2}\right),\left(v_{i+1}, u_{i+1}\right)$, $\left.\left(v_{i+2}, u_{i+1}\right),\left(u_{i+1}, u_{i+2}\right),\left(v_{i+2}, u_{i+2}\right),\left(u_{i+2}, u_{i+3}\right),\left(v_{i+4}, u_{i+2}\right),\left(u_{i+2}, u_{i+4}\right)\right\}$ karena berdasarkan definisi bilangan dominasi vertex-edge $u_{i}$ bersisian dengan $\left\{\left(u_{i-2}, u_{i}\right),\left(u_{i-1}, u_{i}\right),\left(v_{i}, u_{i}\right),\left(v_{i+2}, u_{i}\right)\right.$, $\left.\left(u_{i}, u_{i+1}\right),\left(u_{i}, u_{i+2}\right)\right\}$ dan $u_{i}$ bersisian dengan sisi yang bertetangga dengan $\left\{\left(u_{i-2}, u_{i}\right),\left(u_{i-1}, u_{i}\right)\right.$, $\left.\left(v_{i}, u_{i}\right),\left(v_{i+2}, u_{i}\right),\left(u_{i}, u_{i+1}\right),\left(u_{i}, u_{i+2}\right)\right\}$ yaitu $\left\{\left(u_{i-4}, u_{i-2}\right),\left(u_{i-3}, u_{i-2}\right),\left(v_{i-2}, u_{i-2}\right),\left(u_{i-2}, u_{i-1}\right)\right.$, $\left(v_{i}, u_{i-2}\right),\left(v_{i-1}, u_{i-1}\right),\left(v_{i}, u_{i-1}\right),\left(v_{i+1}, u_{i+1}\right),\left(v_{i+2}, u_{i+1}\right),\left(u_{i+1}, u_{i+2}\right),\left(v_{i+2}, u_{i+2}\right),\left(u_{i+2}, u_{i+3}\right)$, $\left.\left(v_{i+4}, u_{i+2}\right),\left(u_{i+2}, u_{i+4}\right)\right\}$. Akibatnya setiap simpul bisa mendominasi maksimal 20 sisi disekitarnya. Untuk $u_{i}$ lainnya, tidak bisa mendominasi lebih dari 20 sisi. Oleh karena itu dapat dipilih salah satu himpunan dominasi vertex-edge pada $M\left(P_{n}^{*}\right)$ yaitu

(i) untuk $n$ genap maka himpunan dominasi vertex-edge yaitu $\left\{u_{2}, u_{6}, u_{10}, \ldots, u_{4}\left[\frac{n}{2}\right]-2\right\}$,

(ii) untuk $n$ ganjil maka himpunan dominasi vertex-edge yaitu $\left\{u_{1}\right\} \cup\left\{u_{4\left(\left|\frac{n}{2}\right|-1\right)}\right\}$.

Sehingga diperoleh bilangan dominasi vertex-edge $\gamma_{v e}\left(M\left(P_{n}^{*}\right)\right) \leq\left[\frac{n}{2}\right]$. Selanjutnya akan ditunjukkan bilangan dominasi vertex-edge minimum pada middle graph dari graf centipede adalah $\gamma_{v e}\left(M\left(P_{n}^{*}\right)\right)=$ $\left\lceil\frac{n}{2}\right\rceil$. Andai $\gamma_{v e}\left(M\left(P_{n}^{*}\right)\right)=\left\lceil\frac{n}{2}\right\rceil-1$, maka terdapat $\left\lceil\frac{n}{2}\right\rceil-1$ simpul yang merupakan kardinalitas minimum dari himpunan dominasi vertex-edge pada middle graph dari graf centipede. Jika terdapat $\left\lceil\frac{n}{2}\right\rceil-1$ simpul pada himpunan dominasi vertex-edge yang dipilih sembarang, bisa dipilih pada simpul yang mendominasi paling minimum yaitu 3 sisi sampai yang paling maksimum yaitu 20 sisi maka mengakibatkan terdapat minimal satu sisi pada graf $M\left(P_{n}^{*}\right)$ tidak terdominasi. Untuk $n$ genap maka terdapat 4 sisi yang tidak terdominasi dan untuk $n$ ganjil maka terdapat 2 sisi yang tidak terdominasi. Hal tersebut bertentangan dengan Definisi 6, dengan kata lain haruslah $\gamma_{v e}\left(M\left(P_{n}^{*}\right)\right)=\left\lceil\frac{n}{2}\right\rceil$. Jadi dapat disimpulkan bilangan dominasi vertex-edge pada middle graph dari graf centipede yaitu $\gamma_{v e}\left(M\left(P_{n}^{*}\right)\right)=$ $\left\lceil\frac{n}{2}\right\rceil$.

Untuk selanjutnya diperoleh formula bilangan dominasi edge-vertex pada graf $M\left(P_{n}^{*}\right)$.

Proposisi 21 Jika $M\left(P_{n}^{*}\right)$ adalah middle graph dari graf centipede maka $\gamma_{e v}\left(M\left(P_{n}^{*}\right)\right)=n$.

Bukti : Ambil $\left(u_{i}, u_{i+2}\right) \in E\left(M\left(P_{n}^{*}\right)\right)$ dengan $i=4,6,8, \ldots, 2 n-6, i$ genap dan $\left(u_{i}, u_{i+2}\right)$ salah satu sisi dengan derajat simpul penghubung tertinggi sehingga $\left(u_{i}, u_{i+2}\right)$ mendominasi simpul $\left\{u_{i-2}, u_{i-1}, v_{i}, u_{i}, u_{i+1}, v_{i+2}, u_{i+2}, u_{i+3}, v_{i+4}, u_{i+4}\right\}$ karena berdasarkan definisi bilangan dominasi edge-vertex $\left(u_{i}, u_{i+2}\right)$ bersisian dengan $\left\{u_{i}, u_{i+2}\right\}$ dan $\left(u_{i}, u_{i+2}\right)$ bertetangga dengan simpul $\left\{u_{i-2}, u_{i-1}, v_{i}, u_{i+1}, v_{i+2}, u_{i+3}, v_{i+4}, u_{i+4}\right\}$. Akibatnya setiap sisi bisa mendominasi maksimal 10 simpul disekitarnya. Untuk $\left(u_{i}, u_{i+2}\right)$ lainnya, tidak bisa mendominasi lebih dari 10 simpul. Oleh karena itu dapat dipilih salah satu himpunan dominasi edge-vertex pada $M\left(P_{n}^{*}\right)$ yaitu $\left\{\left(u_{1}, v_{2}\right),\left(u_{3}, v_{4}\right),\left(u_{5}, v_{6}\right), \ldots,\left(u_{2 n-1}, v_{2 n}\right)\right\}$ sehingga diperoleh $\gamma_{e v}\left(M\left(P_{n}^{*}\right)\right) \leq n$. Selanjutnya akan ditunjukkan bilangan dominasi vertex-edge minimum pada middle graph dari graf centipede adalah $\gamma_{e v}\left(M\left(P_{n}^{*}\right)\right)=n$. Andai $\gamma_{e v}\left(M\left(P_{n}^{*}\right)\right)=n-1$, maka terdapat $n-1$ sisi yang merupakan kardinalitas minimum dari himpunan dominasi edge-vertex pada middle graph dari graf centipede. Jika terdapat $n-$ 1 sisi pada himpunan dominasi edge-vertex yang dipilih sembarang, bisa dipilih pada sisi yang mendominasi paling minimum yaitu 4 simpul sampai yang paling maksimum yaitu 10 simpul maka mengakibatkan terdapat satu simpul pada graf $M\left(P_{n}^{*}\right)$ tidak terdominasi. Hal tersebut bertentangan dengan Definisi 5, dengan kata lain haruslah $\gamma_{e v}\left(M\left(P_{n}^{*}\right)\right)=n$. Jadi dapat disimpulkan bilangan dominasi edge-vertex pada middle graph dari graf centipede yaitu $\gamma_{e v}\left(M\left(P_{n}^{*}\right)\right)=n$. 


\section{KESIMPULAN}

Bilangan dominasi edge-vertex adalah kardinalitas minimum dari himpunan dominasi edgevertex dan bilangan dominasi vertex-edge adalah kardinalitas minimum dari himpunan dominasi vertexedge. Bilangan dominasi edge-vertex dan vertex-edge pada graf lintasan, cycle dan centipede serta middle graph dari graf lintasan, cycle dan centipede diperoleh dengan cara mencari satu persatu bilangan dominasi edge-vertex dan vertex-edge dari beberapa graf yang dibahas sehingga diperoleh pola bilangan dominasi edge-vertex dan vertex-edge pada masing-masing graf.

Pada Tabel 1 disajikan hasil bilangan dominasi edge-vertex dan vertex-edge pada graf lintasan, cycle dan centipede serta pada middle graph dari graf-graf tersebut.

Tabel 1 Bilangan Dominasi Edge-Vertex dan Vertex-Edge

\begin{tabular}{|c|c|c|c|}
\hline No & Jenis Graf & $\begin{array}{c}\text { Bilangan dominasi edge- } \\
\text { vertex }\end{array}$ & $\begin{array}{c}\text { Bilangan dominasi } \\
\text { vertex-edge }\end{array}$ \\
\hline 1 & Graf Lintasan $\left(P_{n}\right)$ & $\left\lceil\frac{n}{4}\right\rceil$ & $\left\lceil\frac{n}{4}\right\rceil$ \\
\hline 2 & Graf Cycle $\left(C_{n}\right)$ & $\left\lceil\left\lceil\frac{n}{2}\right\rceil\right.$ & $\left\lceil\frac{n}{4}\right\rceil$ \\
\hline 3 & Graf Centipede $\left(P_{n}^{*}\right)$ & $\left\lceil\frac{n}{3}\right\rceil$ & $\left\lceil\frac{n-1}{3}\right\rceil$ \\
\hline 4 & $\begin{array}{c}\text { Middle Graph dari Graf } \\
\text { Lintasan }\left(M\left(P_{n}\right)\right)\end{array}$ & $\left\lceil\frac{n}{3}\right\rceil$ & $\left\lceil\frac{n}{3}\right\rceil$ \\
\hline 5 & $\begin{array}{c}\text { Middle Graph dari Graf } \\
\text { Cycle }\left(M\left(C_{n}\right)\right)\end{array}$ & $n$ & $\left\lceil\frac{n}{2}\right\rceil$ \\
\hline 6 & $\begin{array}{c}\text { Middle Graph } \text { dari Graf } \\
\text { Centipede }\left(M\left(P_{n}^{*}\right)\right)\end{array}$ & & \\
\hline
\end{tabular}

\section{DAFTAR PUSTAKA}

[1] Munir, R. Matematika Diskrit Ed ke-3. Bandung: Teknik Informatika; 2010.

[2] Santoso, B.; Djuwandi dan Soelistyo, R. H. Bilangan Dominasi dan Bilangan Kebebasan Graf Bipartit Kubik. Jurnal Matematika. 2012; Vol. 15, No. 1.

[3] Haynes, T. W.; Hedetniemi, S. T. dan Slater, P. J. Fundamental of Domination in Graphs. New York: Marcel Dekker. 1998.

[4] Vijayan, A. dan Beula, J. S. Edge-Vertex Dominating Sets and Edge-Vertex Domination Polynomials of Centipedes. Indian Journal of Research Foundation. 2016; Vol. 5.

[5] Vijayan, A. dan Nagarajan, T. Vertex-Edge Domination Polynomials of Lollipop Graphs. International Journal of Scientific and Innovative Mathematical Research. 2015; Vol. 3.

[6] Vaidya, S. K. dan Shah, N. H. Prime Cordial Labelling of Some Graphs. Open Journal of Discrete Mathematics. 2012.

[7] Vaidya, S. K. dan Bantva, D. D. The L(2,1)-Labeling of Some Middle Graphs. Journal of Applied Computer Science \& Mathematics. 2010; 9(4):104-107.

[8] Vijayan, A. dan Nagarajan, T. Vertex-Edge Dominating Sets and Vertex-Edge Domination Polynomials of Paths. International Journal of Mathematics Trends and Technology. 2013; Vol 4.

[9] Vijayan, A. dan Beula, J. S. Edge-Vertex Dominating Sets and Edge-Vertex Domination Polynomials of Cycle. Open Journal of Discrete Mathematics. 2015; Vol 5.

EVI UTAMI

EVI NOVIANI

FRANSISKUS FRAN : Jurusan Matematika FMIPA UNTAN, Pontianak
: Jurusan Matematika FMIPA UNTAN, Pontianak eviutami46@gmail.com

: Jurusan Matematika FMIPA UNTAN, Pontianak evinnoviani@math.untan.ac.id fransiskusfran@math.untan.ac.id 